\title{
Pandemics, food (in)security, and leaving the EU: What does the Covid-19 pandemic tell us about food insecurity and Brexit
}

\author{
Ronald Ranta ${ }^{a, *}$, Hilda Mulrooney ${ }^{\mathrm{b}}$

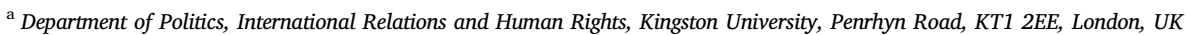 \\ ${ }^{\mathrm{b}}$ Associate Professor in Nutrition at Kingston University, London, UK
}

\section{A R T I C L E I N F O}

\section{Keywords:}

Food (in)security

Brexit

Free trade agreements

Nutrition

Inequalities

\begin{abstract}
A B S T R A C T
Focusing on food (in)security, this paper argues that the Covid-19 pandemic has shed light on what has been so far neglected in the on-going Brexit discussions. The current pandemic has produced startling images of empty supermarket shelves, shortages of farm workers, increased use of food banks and heightened concern over the health of those at the lower end of the socio-economic scale. We argue that food insecurity was not created by the current pandemic but is a serious underlying issue in the UK, which has not been adequately considered in discussions about Brexit. In other words, the pandemic has simply highlighted the risk that Brexit will worsen food insecurity and the health of those already disadvantaged. We argue that the pandemic provides an opportunity for UK policy makers to consider the impact of food trade deals on food insecurity, one which we urge them to take.
\end{abstract}

\section{Introduction}

The purpose of this commentary article is to examine food (in)security in the UK in light of the Covid-19 pandemic but also crucially, in light of the government's insistence on leaving the European Union (EU) at the end of 2020, with or without a deal, and the impact that might have. The early weeks of the pandemic, and the ensuing lockdown, revealed scenes of empty supermarket shelves; panic buying; many families and vulnerable groups struggling to access food; and farmers unable to find enough workers to pick fruit and vegetables. Even more worrying, the pandemic exposed a number of the fragilities and inequalities in the UK food system in relation to food security. From an overreliance on a 'just-in-time' food distribution model and poorly paid migrant and transitory food labour force to rising levels of malnutrition and use of food banks; it is important to note that much of what had been exposed predates the pandemic. The pandemic simply highlighted issues that have not been properly addressed by successive UK governments over the past decade. Below we list some of these food security issues and discuss them in relation to the Covid-19 pandemic and Brexit. Our main concern is that the food (in) security problems the UK is facing, and which have been exposed by the pandemic, may be further exacerbated by the UK's decision to leave the EU.

\section{Problems and challenges of the UK food system in relation to food security}

The problems that have been exposed by the pandemic are varied and multifaceted. For the purpose of this commentary article we will focus on two specific areas, household food insecurity and structural issues affecting how food is grown, produced and imported. Household food insecurity, and in particular child food insecurity, has become a major news story during the pandemic. This is because of the dramatic increase in the use of food banks and food charities (see, for example, Fairshare, 2020; Loopstra, 2020; and The Trussell Trust, 2020) and the campaign led by the footballer Marcus Rashford to provide free school meals for eligible children during holiday periods (Richardson, 2020). There is no doubt that household food insecurity has risen during the pandemic. What is perhaps less well recognised is that it has increased from an already high baseline. Food insecurity, defined as 'a household-level economic and social condition of limited or uncertain access to adequate food' (The Trussell Trust, 2019), was estimated to affect 8-10\% of UK households between 2016 and 2018 (Institute of Health Equity, 2010). In its July 2018 report, the UK Stakeholders for Sustainable Development stated that the government 'is failing to address malnutrition in all forms, with food insecurity and obesity rising' and that the 'level of adult food insecurity in the UK is among the worst in Europe, and

\footnotetext{
* Corresponding author.

E-mail addresses: ronald.ranta@kingston.ac.uk (R. Ranta), hilda.mulrooney@kingston.ac.uk (H. Mulrooney).
} 
for children it is one of the worst, if not the worst, performing nations' (UKSSD, 2018). Food insecurity adversely affects both mental and physical health, with impacts in the short and long-term (Gundersen \& Ziliak, 2015; End Hunger, 2019). Young mothers, the unemployed and those on low incomes are more likely to be food insecure, and women more so than men (Institute of Health Equity, 2010).

Food insecurity, poverty, hunger and obesity are all linked through shared causal pathways (House of Commons Environmental Audit Committee, 2019). During the pandemic more people were pushed into food insecurity, with heightened risks of obesity and malnutrition particularly among deprived communities (Food Standard Agency, 2020). This is a cause for concern because people living in deprived areas, particularly those with underlying health conditions, have had higher rates of infection and death from Covid-19 (Public Health England, 2020). Poor diet is a well-recognised contributor to ill health. Recent statistics on dietary intakes paint a stark picture: those who are more deprived are already least likely to eat a nutritious diet (Public Health England, 2019; The Food Foundation, 2016). According to the World Health Organisation (WHO), poor diet is one of four major modifiable risk factors for diseases such as cardiovascular disease, cancer and type 2 diabetes (World Health Organisation, 2018). These diseases are socially patterned; with greater prevalence in more compared with less deprived groups (The King's Fund, 2018), and a greater proportion of people from Black, Asian and minority ethnic (BAME) backgrounds are deprived (ONS, 2018a). Similarly, recent analyses by Public Health England (2020) suggest that BAME groups are more likely to be seriously affected by Covid-19, not because they have greater genetic susceptibility to the virus, but because of their socio-economic conditions. They are more likely to work in places where they are more exposed to infection, to have lower wages, which makes it difficult for them to stop working, and low paid workers are more likely to live in crowded conditions making transmission of the virus easier. They are also more likely to suffer from chronic diseases such as obesity and diabetes, making them more vulnerable to the serious complications of Covid-19. Thus social and nutritional inequality within the UK, well known with regard to risk of chronic diseases, is further exposed by an infectious disease pandemic.

The pandemic has also highlighted several structural weaknesses with regard to the UK's food system which affect food security, in particular the reliance on the 'just-in-time' (JiT) model and on a migrant and seasonal low skilled food labour force. The JiT model has transformed British supermarkets, resulting in lower food costs and greater choice for consumers (Holmes, 2020). It has also meant low levels of UK food stocks, estimated to be around 'three to five days' worth (Lang, 2016); though it is important to note that, according to DEFRA, stocks of different food groups vary, from several weeks for certain dry goods to $24 \mathrm{~h}$ in the case of some fresh produce (Lang, 2019). The early stages of the pandemic, which saw empty supermarket shelves and panic buying, stoked fears of food shortages, albeit temporarily. Panic buying in particular exposed wide spread insecurity about food stocks even among those who would not consider themselves food insecure. This suggests that the JiT model relies on the public's confidence regarding the robustness of the system. In addition, the pandemic further highlighted concerns with regard to the UK's food labour force, exposing the reliance on low paid migrant workers. In order to meet the demands for food labour during the pandemic the government had to waive restriction requirements and fly in workers from Romanian and Bulgaria (O'Carroll, 2020a). It also set up a national campaign to recruit British workers, with minimal success; of 35,000 expressions of interest, only 5500 chose to go for an interview (Reynolds, 2020).

\section{How does this relate to Brexit?}

We argue that the problems highlighted by the pandemic with relation to food insecurity will potentially be further exacerbated by the UK's withdrawal from the EU, and while the effects of the pandemic may be short-term, those of Brexit may be more long-lasting. This will be the case regardless of whether the UK withdraws with a deal or not, though it is clear that a no-deal scenario would make matters worse. We base our argument on a number of factors, but for the sake of brevity we will focus on four below.

First, Brexit, in whatever shape or form, will result in greater disruption to trade between the UK and the EU, which will impact on the JiT model. During the pandemic, supermarkets generally managed the panic buying and early shock well, but there were problems with getting the right supplies to where they were needed, and the whole episode raised questions about the resilience of the UK food supply and distribution networks, particularly post-Brexit (Garnett et al., 2020; Holmes, 2020). These fears reflect the UK's reliance on food imports and its need for frictionless access to Europe. The UK's food sufficiency rate is around $60 \%$, with $40 \%$ of food consumed brought in from elsewhere, the overwhelming majority from and through the EU (Lang, 2020). A recent French trial of new border control measures, which resulted in long delays, highlighted the potential consequences of trade that was not frictionless (O'Carroll, 2020b). According to the Office of Budgetary Responsibility (OBR), border disruption, affecting trade from the EU, is expected to last for up to a year, with the greatest disruption in the first quarter of 2021, even in the case of a trade deal. The OBR also projects that this will be accompanied by extensive disruption to the agriculture sector in the UK, which will be the worst sector affected by Brexit, placing further constraints on the JiT model (OBR, 2020).

It is hard to predict how UK food retailers will manage the Brexit disruption to their food supply chains. UK supermarkets managed to ensure that shelves remained relatively stocked during the height of the pandemic lockdown. Interestingly, it has been suggested that the resilience shown by the sector was due to the preparations made for a no-deal Brexit (Peterson, 2020). What is clear is that Brexit will cause disruptions to trade between the UK and the EU and to the agriculture sector in the UK, which will necessitate a rethinking of the current JiT model (Garnett et al., 2020; Holmes, 2020). A disruption to the JiT model as a result of Brexit would disproportionally impact those at the lower end of the socio-economic scale (Lang, 2019). As we have witnessed with the pandemic, this may also affect the food security of many, including those who had previously thought of themselves as food secure.

Second, some of the issues concerning the JiT model could be mitigated if the UK increased its own food production. However, the Covid19 pandemic has demonstrated a key weakness in UK food labour supply, which will be further exacerbated by the loss of EU workers. The problem of recruiting sufficient food labour is complicated by uncertainty over what will happen once the free movement of workers from the EU ceases. If stricter immigration controls prioritise highly skilled workers, but not seasonal workers from Bulgaria and Romania, where will the necessary food labour come from? It has also become clear that treating seasonal and experienced farm workers as low skilled and poorly paid labour is counterproductive to recruiting more UK based workers (Jones, 2020). In the run up to Brexit, Industry heads have called on the government to either extend current schemes to recruit food labour from outside the UK or 'face price hikes and shortages' (Sandercock, 2020).

Third, the current UK-EU transitional agreement is due to end on December 31, 2020. It is not yet clear at this stage whether the UK will leave with a deal, and as a result most of the models estimating the possible impact of Brexit on food prices have looked at both possibilities. While there is a degree of variation between the models used, they all suggest that food prices are likely to rise after Brexit regardless of whether a UK-EU deal is agreed; the models are clear that food price rises will be higher under a no-deal scenario. This is because, in the absence of an agreement, UK-EU trade will be based on World Trade Organisation rules and will involve the application of tariffs and non-tariffs barriers. The variations between models are to an extent a product of the high degree of uncertainty regarding the negotiations and the impact of a number of different factors, for example: the type of food product analysed; the exact levels of tariffs and non-tariff barriers; the level of support given by the UK to domestic food production; the impact of future 
trade deals; and the degree to which price rises will be passed on to consumers by retailers. Potential Brexit food price rises have been modelled to be as low as 2-3\% (Hubbard, 2019) and as high as 6\% and $22 \%$, in the case of a deal and a no-deal scenario respectively (Barons \& Aspinall, 2020). A recent analysis by the LSE indicates that price rises for branded and specialty food products would likely be $9.9 \%$ in a deal scenario and $26.5 \%$ in a no deal scenario; and for unbranded and more substitutable products $4.7 \%$ in deal and $12.5 \%$ in no deal scenarios (Datta et al., 2020). What is clear is that the likely effect of Brexit, regardless of the shape and form it takes, will be a rise in food prices. As we will explain below, household food insecurity is not simply about food prices. Nevertheless, it is clear that rising food prices will increase household food insecurity and have direct implications for healthcare, particularly those with chronic conditions (Barons \& Aspinall, 2020).

Lastly, it is becoming clearer that regardless of its specific shape or form, Brexit will result in higher unemployment and lower economic growth, at least in the short term, with the agriculture sector particularly badly hit (OBR, 2020). Analysis on behalf of UK in a Changing Europe suggests that Brexit, both with regard to deal and no-deal scenarios, might have a longer negative impact on the economy than the pandemic (Simpson, 2020). It is hard to predict what the long term implications of lower economic growth, higher unemployment and greater economic uncertainty will be for the UK, and whether they will result in higher taxes and or lower public spending. What we can say with a high degree of certainty is that, if the OBR predictions are accurate, Brexit-resultant lower growth and higher unemployment will adversely affect the food security of those who are currently struggling and or those living in deprived areas. It might also push more people into poverty and food insecurity. This will translate into greater household food insecurity in the UK and further rises in the use of food banks and free school meals.

\section{Brexit and the UK's food security problem}

We fully acknowledge that Brexit was never promoted as a solution to the UK's food security problems. 'Taking back control' was the main slogan, and it clearly resonated with much of the British electorate, but it is not clear what this means in term of food policy generally speaking and with regard to food security specifically. Nevertheless, those advocating for Brexit argued that it would enable the UK to better address many of the food problems it faced. In that sense, the pandemic has provided a reality check of what the real food issues are and what the implications for food security are of not addressing them properly.

In many ways food insecurity will be exacerbated not only by the direct and indirect impacts of Brexit, but also by the fact that there was never a clear Brexit food policy and that what was discussed did not try to address the real food insecurity problems. The pro-Brexit campaign, and later the Conservative government, identified low productivity, overbearing EU bureaucracy and food prices as key food issues that needed to be addressed (Ranta, 2019). They asserted that EU food policies, in particular the Common Agricultural Policy (CAP) and Common Fisheries Policy (CFP), were financially wasteful and inefficient; overly regulated to the point of suffocating food producers and economically disadvantageous to consumers; unhelpful to UK farmers and fishermen; ruinous to the environment; artificially inflate food prices; and that they reduced competition and choice for UK consumers. Leaving the EU would, in their view, bring about new free trade agreements (FTAs) with non-EU food producers, such as the US, Canada, and Australia; reduce crippling food regulations and rules; reduce food prices; and allow UK food producers to innovate and raise productivity (Vote Leave, n.d). These ideas by and large underpin Conservative governments' approaches to food after the referendum (Ranta, 2019). Setting aside for the moment whether these ideas put together represent a clear and coherent long term policy direction for food security in the UK, they raise two important questions. First, has the UK government correctly diagnosed the UK food system's problems, particularly with regard to food security? Second, are the Brexit-related remedies it is proposing suitable in addressing the food security problems the UK is facing?

In our view Brexit-inspired Conservative governments have misdiagnosed the problems that affect food policy, and in particular food security. Over the past decade, and despite record levels of employment, the UK witnessed rising levels of food insecurity, including increasing use of food banks (Garthwaite, 2016). Many of the contributing factors, such as the rising levels of inequality and changes to the benefit system, are national rather than related to the EU. Food insecurity in the UK is not primarily about food prices (although this is an important factor), productivity or EU regulations and regulatory bodies. Instead of focusing on the problem of access to adequate and nutritious food, the government appears focused on the issues of choice, deregulation and productivity. Because it has misdiagnosed the problem, the remedies the government has proposed will not alleviate food insecurity in the UK; if anything they could make things worse.

Let us start with the proposal of pursuing FTAs with leading food exporting countries. The EU is a major source of food for the UK. An estimated $30 \%$ of food, $40 \%$ of vegetables and $37 \%$ of fruit consumed in the UK is imported from the EU (End Hunger, 2019; House of Lords European Union Committee, 2018). It is unclear how the UK government proposes to bridge this gap if an agreement cannot be reached with the EU. Any such agreement will require a UK commitment to EU food standards, which will directly affect FTAs with other countries. We accept the argument that negotiating FTAs outside of the EU may well open up the UK food market to cheaper food imports, but this will almost certainly mean accepting lower food standards (Future British Standards Coalition, 2020). While the government has made a commitment that food standards will be maintained and the UK population will not have to accept lower food or hygiene standards (Askew, 2020), this would make it harder to negotiate FTAs. Recently, the government rejected a House of Lords amendment that would have required imported foods to meet UK standards (BBC, 2020). What is far more likely to happen is that the UK will slowly move towards accepting lower food and hygiene standards while continuing to support high UK standards; in other words the creation of a two-tier food system (Benton et al., 2019). Such a system would ensure British food was produced to high standards while allowing cheaper imports that were not, potentially driving UK producers out of business (Millstone et al., 2019). This in our view would be a disastrous policy if pursued by the government, forcing British farmers to compete with cheaper and less regulated imports, while allowing 'cheap' food, of lower nutritional standards and with higher risk, into the UK market.

The second issue that Brexit campaigners focused on is food prices (Ranta, 2019). This is interesting particularly given that pre-pandemic, UK household spending on food was only around $8 \%$ of their budget (excluding eating out), one of the lowest figures in the world (ONS, 2018b). Access to food is an increasingly important issue in the UK, but it is not simply about the price of food. Disparities in intake of nutritious foods, as well as the prevalence of non-communicable diseases including obesity, can be seen across different socioeconomic groups (Foster et al., 2018; PHE, 2019). Successive governments have tried to address this through different policies. Most recently the Obesity Strategy has sought (among other actions) to reduce the promotion of unhealthy foods (high in fat, salt \& sugar), both online and in physical locations, especially to children (DHSC, 2020). The possibility that lower quality food products enter the UK as a consequence of Brexit is incompatible with the public health work which has been carried out for the past years (PHE, 2017), and incompatible with the aim of the current Obesity Strategy (DHSC, 2020). Given that an important aspect of food security is access to 'sufficient, safe \& nutritious food' (FAO, 2003), the potential flooding of the UK food market with cheaper, less safe and less nutritionally valuable food would increase food insecurity. And this is not simply in relation to a potential FTA with the US, which according to the government's own analysis will be worth much less than initially predicted (Department for International Trade, 2020); the incoming President Joe Biden has suggested the US was in no hurry to sign new FTAs (Friedman, 2020). The main food-exporting countries the government has proposed negotiating 
FTAs with, such as the US, Canada, Australia, New Zealand and India, are not seeking the lowering of tariffs, which are already low, but greater access. This implies some UK acceptance of their regulations, labelling and standards, which currently include practices that are either restricted or banned in the EU (Ranta, 2019; Future British Standards Coalition, 2020). Whatever the underlying causes, those with insecure access to food should not be made to take risks with the foods they choose, and those on low incomes are more likely to choose high calorie less nutritious foods (Whybrow et al., 2017).

Lastly, what about CAP and CFP? Will leaving those frameworks improve prospects for food security, and for farmers and fishermen? Analyses suggest that being freed of the yokes of CAP and CFP would in fact make the farmers and fishermen poorer for a long time (Taylor, 2017). While the UK government has never been a very keen supporter of CAP, UK farmers received $£ 3$ billion annually under the policy to sustain their farming. It is estimated about 50-60 per cent of an average UK farm's income comprises a subsidy under CAP. This varies across the UK: in Northern Ireland about 80 per cent of farmers income in is CAP subsidy (House of Lords European Union Committee, 2017). Since Northern Ireland is the poorest nation in the UK, we can see the same pattern here: Brexit is likely to hit the poorest hardest. As for the CFP, the problem would not be the loss of subsidies which would hit the fishermen but the need to put in place an alternative governance structure, which respects the interests of non-industry stakeholders, the competencies of the UK devolved governments and the UN convention on the Law of the Sea (McAngus et al., 2018), as well as a new trade agreement with the biggest buyer of UK fish and the biggest fish and sea food market in the world, the EU (Billiet, 2019).

\section{Conclusion}

The current Covid-19 pandemic has exposed the emptiness behind the Brexit slogans of taking back control, reducing food prices and providing choice. As we have outlined above, Brexit was never meant to address food security issues, with its focus instead on FTAs, deregulation and cheap imports. As we have shown, these do not, and will not provide an adequate remedy to the food security problems the UK is facing, which have only been exacerbated by the pandemic, and they may end up making the situation worse.

The increased use of free school meals and food banks over the past decade and during the pandemic has exposed the structural inequalities that are at the heart of food insecurity in the UK, among the worst in Europe. The food security problems the UK is facing, and which were highlighted by the pandemic, such as inadequate access to sufficient and nutritious food, hunger, malnutrition and obesity are the end result of long-term problems exacerbated by a decade of austerity and insufficient support for vulnerable groups. The Brexit remedy will create an even less secure food environment in the UK and will probably force many vulnerable groups to subsist on cheaper and less safe and nutritious foods. Even in the case of a Brexit deal with the EU, the increase in food prices and the lower economic growth which are predicted by all models, coupled with questions over food labour and the resilience of the JiT food distribution model, have the potential to exacerbate food insecurity in the UK and for the most vulnerable citizens.

Lastly, in our view, any future trade deals should be independently scrutinised for their potential impact on food insecurity. Poor diet is a major modifiable risk factor for chronic diseases, which have been major causes of death and disability in the UK for many years, and are socially patterned. Hasty food compromises may inadvertently increase food insecurity and we may not see the effects of this on chronic disease for many decades. The price for failing to tackle food insecurity or compromising over it in the pursuit of FTAs will be borne by the most vulnerable in society. The pandemic has provided us with a chance to rectify and alleviate food insecurity; it should be a rallying cry.

\section{Declaration of competing interest}

The authors have no conflicts of interests to declare.

\section{References}

Askew, K. (2020). UK food sceptical as government insists 'no dilution of standards' for post-Brexit trade deals. Available from: https://www.foodnavigator.com/Article/20 20/01/10/UK-food-sceptical-as-government-insists-no-dilution-of-standards-for-po st-Brexit-trade-deals. (Accessed 23 November 2020).

Barons, M. J., \& Aspinall, W. (2020). Anticipated impact of Brexit scenarios on UK food prices and implications for policies on poverty and health: A structured expert judgement approach. BMJ Open. https://doi.org/10.1136/bmjopen-2019-032376

Bbc. (2020). Agriculture bill: Bid to protect post-Brexit food standards rejected, 12 October 2020. Available from: https://www.bbc.co.uk/news/uk-politics-54506185. (Accessed 20 November 2020).

Benton, G., et al. (2019). Food politics and policies in post-brexit britain. A Chatham House Research paper.

Billiet, S. (2019). Brexit and fisheries: Fish and chips aplenty? The Political Quarterly, 90(4), 611-619.

Datta, N., et al. (2020). Vulnerabilities of supply chains post Brexit: Report. Available from: https://www.lse.ac.uk/business-and-consultancy/consulting/assets/docu ments/vulnerabilities-of-supply-chains-post-brexit-final-report.pdf. (Accessed 23 November 2020).

Department for Health and Social Care. (2020). Tackling obesity: Empowering adults and children to live healthier lives. Available from: https://www.gov.uk/government/pu blications/tackling-obesity-government-strategy/tackling-obesity-empowering-a dults-and-children-to-live-healthier-lives. (Accessed 20 November 2020).

Department for International Trade. (2020). UK-US free trade agreement. Available from: https://assets.publishing.service.gov.uk/government/uploads/system/uploads/a ttachment_data/file/869592/UK_US_FTA_negotiations.pdf. (Accessed 23 April 2020).

End Hunger. (2019). Why end UK hunger? The health case. Available from: https:// www.endhungeruk.org/2019/11/22/health/. (Accessed 18 April 2020).

Fairshare. (2020). Mammoth covid-19 response sees 16 million meals provided to UK's most vulnerable through pandemic. Available from: https://fareshare.org.uk/newsmedia/news/mammoth-covid-19-response-sees-16-million-meals-provided-to-uksmost-vulnerable-through-pandemic/. (Accessed 18 November 2020).

FAO. (2003). Trade reforms and food security. Conceptualising the linkages. Available from: http://www.fao.org/3/y4671e/y4671e00.htm\#Contents. (Accessed 22 April 2020).

Food Standard Agency. (2020). The covid-19 consumer research. Available from: htt ps://www.food.gov.uk/research/research-projects/the-covid-19-consumer-research. (Accessed 20 November 2020).

Foster, M. E. H., Celis-Morales, C. A., Nicholl, B. I., Petermann-Rocha, F., Pell, J. P., Gill, J. M. R., et al. (2018). The effect of socioeconomic deprivation on the association between an extended measurement of unhealthy lifestyle factors and health outcomes: A prospective analysis of the UK biobank cohort. Lancet Public Health, 3, e576-e585. https://doi.org/10.1016/S2468-2667(18)30200-7

2 December 2020 Friedman, T. (2020). 'Biden made sure "trump is not going to Be president for four more years"'. New York Times. Available from:

https://www.nytimes.com/2020/12/02/opinion/biden-interview-mcconnell-ch ina-iran.html?action $=$ click\&module $=$ Opinion\&pgtype $=$ Homepage (Accessed 1 December 2020).

Future British Standards Coalition. (2020). Safeguarding standards. Available from: https://www.sustainweb.org/resources/files/reports/Future\%20British\%20Stan dards\%20Coalition\%20-\%20Safeguarding\%20Standards.pdf. (Accessed 4 December 2020).

Garnett, P., et al. (2020). Vulnerability of the United Kingdom's food supply chains exposed by Coivd-19. Nature Food, 1, 315-318. https://doi.org/10.1038/s43016 020-0097-7

Garthwaite, K. (2016). Hunger pains: Life inside foodbank britain. Bristol, Policy Press.

Gundersen, C., \& Ziliak, J. P. (2015). Food insecurity and health outcomes. Health Affairs. https://doi.org/10.1377/hlthaff.2015.0645

Holmes, H. (2020). Food security: Are we cutting food too fine with our just in time supply chain?, 14 May 2020. Available from: https://www.thegrocer.co.uk/supply-chai n/food-security-do-we-need-to-rethink-our-just-in-time-supply-chain-post-coronavi rus/604872.article. (Accessed 21 November 2020).

House of Commons Environmental Audit Committee. (2019). Hunger, malnutrition and food insecurity in the UK. Available from: https://www.parliament.uk/business/co mmittees/committees-a-z/commons-select/environmental-audit-committee/. (Accessed 21 April 2020).

House of Lords European Union Committee. (2018). Brexit: Food prices and availability. Available from: https://publications.parliament.uk/pa/ld201719//dselect/ldeucom/ 129/129.pdf. (Accessed 21 April 2020).

House of Lords, European Union. (2017). Brexit: Agriculture, chapter 5 withdrawing from CAP financial support. Available from: https://publications.parliament .uk/pa/ld201617/ldselect/ldeucom/169/16908.htm\#_idTextAnchor092. (Accessed 21 April 2020).

Hubbard, C. (Ed.). (2019). Brexit: How might UK agriculture survive and thrive?'. Available from: https://ukandeu.ac.uk/wp-content/uploads/2019/11/Final-Report-Brexitand-Agriculture-March2019.pdf. (Accessed 18 April 2020).

Institute of Health Equity. (2010). Health equity in England: The marmot review 10 years on. Available from: https://www.health.or

g.uk/sites/default/files/upload/publications/2020/Health\%20Equity $\% 20$ in $\%$ 
20England_The\%20Marmot\%20Review\%2010\%20Years\%200n_full\%20report.pdf. (Accessed 18 April 2020).

Jones, S. (2020). 'Anyone who's been laid off can pick fruit right? It's not that simple', the guardian, 17 Apr 2020. Available from: https://www.theguardian.com/commenti sfree/2020/apr/17/laid-off-pick-fruit-seasonal-workers-special-skills. (Accessed 26 April 2020).

Lang, T. (2016). 'How Brexit threatens britain's food security', the conversation, 30 june 2016 Available from: https://theconversation.com/how-brexit-threatens-britains-food-s ecurity-61716. (Accessed 26 April 2020).

Lang, T. (2019). No-deal food planning in UK Brexit. Lancet, 394(10201), 7-13.

Lang, T. (2020). Feeding britain: Our food problems and how to fix them. Pelican Books.

Loopstra, R. (2020). Vulnerability to Food Insecurity Since the Covid-19 Lockdown. Preliminary report. Availabel from https://foodfoundation.org.uk/wp-content/uploa ds/2020/04/Report_COVID19FoodInsecurity-final.pdf. (Accessed 4 December 2020).

McAngus, C., et al. (2018). Governing UK Fisheries after Brexit: Lessons from Iceland, Norway and the Faroe Islands. Available from: https://ukandeu.ac.uk/wp-content/uploads/ 2018/05/Governing-UK-fisheries-after-Brexit-Lessons-from-iceland-Norway-and-theFaroe-Islands.pdf. (Accessed 26 April 2020).

Millstone, E., et al. (2019). Food Brexit and chlorinated chicken: A microcosm of wider food problems. The Political Quarterly, 90(4), 645-653.

Office for Budget Responsibility. (2020). Economic and fiscal outlook: November 2020. Available from: http://cdn.obr.uk/CCS1020397650-001_OBR-November202 0-EFO-v2-Web-accessible.pdf. (Accessed 25 November 2020).

Office for National Statistics. (2018a). People living in deprived neighbourhoods. Available from: https://www.ethnicity-facts-figures.service.g ov.uk/uk-population-by-ethnicity/demographics/people-living-in-deprived-neigh bourhoods/latest\#full-page-history. (Accessed 15 November 2020).

Office of National Statistics. (2018b). Family Spending in the UK: April 2017 to march 2018. Available from: https://www.ons.gov.uk/peoplepopulationandcommunity/pe rsonalandhouseholdfinances/expenditure/bulletins/familyspendingintheuk/financia lyearending2018. (Accessed 8 May 2020).

O'Carroll, L. (2020a). 'Romanian fruit pickers flown to UK amid crisis in farming sector', the Guardian, 15 April 2020. Available from: https://www.theguardian.com/worl d/2020/apr/15/romanian-fruit-pickers-flown-uk-crisis-farming-sector-coronavirus. (Accessed 16 April 2020).

O'Carroll, L. (2020b). 'Trail of Brexit border checks causes five mile lorry queues in Kent', the Guardian, 24 November 2020. Available from: https://www.theguardian.com/pol itics/2020/nov/24/trial-of-brexit-border-checks-causes-five-mile-lorry-queues-in-ke nt. (Accessed 24 November 2020).

Peterson, S. (2020). 'Brexit's benefits? How food security prep set up UK for pandemic', 28 May 2020. The Christian Science Monitor. Available from: https://www.csmonitor .com/World/Europe/2020/0528/Brexit-s-benefits-How-food-security-prep-set -up-UK-for-pandemic. (Accessed 17 November 2020).

Public Health England. (2017). Sugar reduction and wider reformulation. Available from: https://www.gov.uk/government/collections/sugar-reduction. (Accessed 3 December 2020).

Public Health England. (2019). National diet and nutrition survey years 1 to 9 of the rolling programme (2008/2009-2016/2017): Time trend and income analyses. Availably from https://assets.publishing.service.gov.uk/government/uploads/system/uploads/atta chment_data/file/772434/NDNS_UK_Y1-9_report.pdf. (Accessed 3 December 2020).

Public Health England. (2020). Disparities in the risk and outcomes of Covid-19. https://a ssets.publishing.service.gov.uk/government/uploads/system/uploads/attachment_ data/file/908434/Disparities_in_the_risk_and_outcomes_of_COVID_August_2020_ update.pdf. (Accessed 17 November 2020).

Ranta, R. (2019). Dissonance on the Brexit menu: What does britain want to eat? The Political Quarterly, 90(4), 654-663.

Reynolds, E. (2020). Coronavirus may force the UK to rethink its relationship with migrant workers. Available from: https://edition.cnn.com/2020/04/17/europe/migr ant-workers-uk-coronavirus-gbr-intl/index.html. (Accessed 22 April 2020).

Richardson, H. (2020). Marcus Rashford welcomes school holiday support climbdown', BBC, 8 november 2020. Available from: https://www.bbc.co.uk/news/education -54841316. (Accessed 18 November 2020).

Sandercock, H. (2020). 'Extend non-UK labour scheme or face price hikes and shortages, growers warn', the Grocer, 28 October 2020. Available from: https://www.thegrocer .co.uk/brexit-and-the-workforce/extend-non-uk-labour-scheme-or-face-price-hikesand-shortages-growers-warn/649796.article. (Accessed 17 November 2020).

Simpson, T. (2020). 'The UK economy: Brexit vs covid-19', UK in a changing Europe, 24 August 2020. Available from: https://ukandeu.ac.uk/the-uk-economy-brexit-vscovid-19/. (Accessed 15 November 2020).

Taylor, R. (2017). 'Britain's farmers get £3bn a year from the inefficient CAP: That has to change'. Available from: https://blogs.lse.ac.uk/brexit/2017/05/26/britains-fa rmers-get-3bn-a-year-from-the-inefficient-cap-that-has-to-change/. (Accessed 24 April 2020).

The Food Foundation. (2016). Food and the EU referendum. Available from: https ://foodfoundation.org.uk/wp-content/uploads/2016/07/food-and-eu-ref-policy-br iefing-1.pdf. (Accessed 22 April 2020).

The King's Fund. (2018). Long-term conditions and multi-morbidity. Availabelf rom: htt ps://www.kingsfund.org.uk/projects/time-think-differently/trends-disease-and-di sability-long-term-conditions-multi-morbidity. (Accessed 21 April 2020).

The Trussell Trust. (2020). The long read: Food banks have been busier than ever. Available from: https://www.trusselltrust.org/2020/11/13/the-long-read-1/. (Accessed 18 November 2020).

The Trussell Trust. (2019). The State of Hunger. Introduction to a study of poverty and food insecurity in the UK. https://www.trusselltrust.org/wp-content/uploads/sites/2/2 019/06/SoH-Interim-Report-Final-2.pdf. (Accessed 18 April 2020).

UKSSD. (2018). Measuring Up: How the UK is Performing on the UN Sustainable Development Goals. Available at: https://www.ukssd.co.uk/measuringup. (Accessed 15 May 2020).

Vote Leave Briefing Note (n.d) 'The CAP and CFP are wasteful and bureaucratic'. Available from: http://www.voteleavetakecontrol.org/briefing_food.html (accessed 19 April 2020).

Whybrow, S., et al. (2017). Social deprivation is associated with poorer adherence to healthy eating dietary goals: Analysis of household food purchases. Journal of Public Health, 40(1). https://doi.org/10.1093/pubmed/fdx007

World Health Organisation. (2018). Noncommunicable Diseases. Available from: https ://www.who.int/news-room/fact-sheets/detail/noncommunicable-diseases. (Accessed 18 November 2020). 